Cahiers $d u$ MONDE RUSSE

\section{Cahiers du monde russe}

Russie - Empire russe - Union soviétique et États indépendants

$50 / 2-3 \mid 2009$

L'Europe orientale, 1650-1730. Crises, conflits et renouveau

\title{
ПУБЛИКАЦИЯ ИСТОЧНИКОВ XVI-XVIII СТ. В ПОСТСОВЕТСКОЙ УКРАИНЕ
}

Des problèmes de publication et d'interprétation des sources des XVI ${ }^{e}-X V I I^{e}$ siècles en Ukraine postsoviétique

Publication of sixteenth- to eighteenth-century sources in Post-Soviet Ukraine

\section{Елена Русина}

\section{(2) OpenEdition}

\section{Journals}

\section{Édition électronique}

URL : https://journals.openedition.org/monderusse/9719

DOI : 10.4000/monderusse. 9719

ISSN : $1777-5388$

\section{Éditeur}

Éditions de l'EHESS

\section{Édition imprimée}

Date de publication : 15 septembre 2009

Pagination : 347-359

ISBN : 978-2-7132-2260-3

ISSN : $1252-6576$

\section{Référence électronique}

Елена Русина, «Публикация источников xvI-хvIII ст. в постсоветской Украине», Cahiers du monde russe [Онлайн], 50/2-3 | 2009, Выложить онлайн 13 octobre 2012, Наводить справки в 04 septembre 2022. URL: http://journals.openedition.org/monderusse/9719; DOI: https://doi.org/ $10.4000 /$ monderusse. 9719 


\section{ПУБЛИКАЦИЯ ИСТОЧНИКОВ XVI-XVIII СТ. В ПОСТСОВЕТСКОЙ УКРАИНЕ}

Очевидно, нет нужды доказывать, что изменения, происшедшие в украинской историографии в постсоветский период, прямо связаны с новыми политическими реалиями, которыми ознаменовалось начало 1990-х годов. Распад Советского Союза открыл эпоху невероятно быстрых изменений во всех сферах жизни, которые неизбежно сказались на исторической науке, оказавшейся востребованной, как никогда ранее. Коснулись они и такой отдаленной, на первый взгляд, от политической практики сферы, как изучение и публикация источников, которые на украинских землях приобретают массовый характер с конца XV ст., когда формируются первые дошедшие до наших дней документальные комплексы. На первый взгляд, изменения эти имели позитивный характер. В 1991 г. в рамках Национальной Академии наук Украины на основе преобразованной Археографической комиссии, практически без-действовавшей долгие десятилетия, возник Институт украинской археографии и источниковедения, получивший впоследствии имя Грушевского. Его созданию предшествовала масштабная конференция «Украинская археография: Современное состояние и перспективы развития», наметившая грандиозные планы научноисследовательской и издательской деятельности будущего академического учреждения на период до 2000-2005 гг. ${ }^{1}$

Особое место при этом отводилось нарративным и документальным памятникам эпохи позднего средневековья и раннего нового времени ${ }^{2}$, по

1. См. ее материалы: Украӥнська археографія: сучасний стан та перспективи розвитку, К., 1988.

2. Уместно отметить, что некоторые авторитетные украинские исследователи (в частности, издатели периодического сборника «Mediaevalia Ucrainica») предпочитают оперировать термином «долгое средневековье», применимым, по их мнению, к украинской истории вплоть до конца XVIII ст. 
сути, игнорировавшимся советской археографией (как отмечалось на конференции, из почти 300 изданий источников, осуществленных в УССР, так называемой «дооктябрьской» проблематике было посвящено лишь несколько десятков, - как правило, вышедших в свет на гребне национального подъема 1920-х - начала 1930-х годов; не удивительно, что звучали даже предложения полностью исключить советскую тематику из планов работы будущего института).

Однако действительность оказалась далекой от очерченных на пике Горбачевской перестройки радужных перспектив. Из намеченного удалось осуществить весьма немного. Пресловутый остаточный принцип финансирования науки в условиях социально-экономического кризиса 1990х годов привел к оттоку и без того немногочисленных квалифицированных кадров и свертыванию эдиционной работы института. Прекратилось даже издание «Украинского археографического ежегодника», призванного служить «опознавательным знаком» института: два первых его выпуска увидели свет в 1992-1993 гг., тогда как выпуск 3/4, датированный 1999 г., фактически вышел в 2001 г.

При этом, с одной стороны, сразу наметился «перекос» в сторону современной тематики, a, с другой, - произошло рассеивание научных сил на разных направлениях издательской работы, в силу чего реальные достижения на важнейших из них оказались очень и очень незначительными. Как правило, это публикации источников, осуществленные в начале 1990-х годов: описание Украины Боплана (включающее факсимильное воспроизведение французского издания), хроника Феодосия Софоновича и др. ${ }^{3}$

Основной продукцией института стали малотиражные брошюры серии «Научно-справочные издания по истории Украины», тогда как собственно археографию представляла документальная серия «Источники по новейшей истории Украины» (тематические сборники, посвященные преимущественно таким болезненным для национального сознания и замалчивавшимся в советской историографии вопросам, как голод 1933 г., сталинские репрессии, деятельность Украинской повстанческой армии (УПА) и т.п.). По сути, «Летопись УПА» стала для института куда более приоритетной, чем украинские летописи XVI-XVIII вв. Был полностью предан забвению проект известного исследователя Юрия Мицыка, предполагавший издание

3. Боплан Г.Л., Опис Украӥни [Guillaume Le Vasseur sieur de Beauplan, Description d'Ukranie], К., Кембрідж, 1990; В.М. Кравченко, Н.М. Яковенко, сост., Торгівля на Україні. XIV - середина XVII століття: Волинь і Наддніпрянщина, К.: Наукова Думка, 1990; Ф. Софонович, Хроніка з літописиів стародавніх, К., 1992. 
специальной археографической серии, посвященной памятникам летописания и включающей, как минимум, 12 томов ${ }^{4}$.

Не менее досадно, что не были реализованы проекты, близкие к осуществлению, как-то публикации списка Ипатьевской летописи, вышедшего из-под пера киевского монаха Марка Бундура (1655 г.), и так называемой летописи Боболинского - Украинского хронографа 2-ой редакции, фрагментарно опубликованного по позднему списку в «Полном собрании русских летописей» (Т. 32. - М., 1975) под названием «Хроника литовская и жмойтская». Обе летописи готовились к изданию учениками Ю. Мицыка, и то, что они так и не увидели свет, служит лишь одним из индикаторов кризиса, поразившего некогда знаменитую днепропетровскую школу источниковедения.

В то же время дистанцирование постсоветских государств помешало реализации совместных археографических проектов, разрабатывавшихся медиевистами союзных республик, начиная с 1980-х гг. Среди них следует, в частности, упомянуть план корпусной публикации книг Литовской Метрики - архива государственной канцелярии Великого княжества Литовского, которое, как известно, в XIV-XVI вв. включало в свой состав все белорусские и основной массив украинских земель. В 1980-е гг., когда были разработаны методические рекомендации по изданию Литовской Метрики, увидели свет лишь две польские публикации. С начала 1990-х годов этот проект осуществлялся исключительно силами Института истории Литвы 5 Он включен в программу 1000-летия Литвы, а его участники получили престижные научные премии. В 2000 г. к нему подключился Институт истории Национальной академии наук Беларуси.

Заслуживает упоминания и несостоявшийся российско-украинский проект издания Густынской летописи. Ныне она опубликована по одному из восьми сохранившихся списков в серии «Полное собрание русских летописей» (Т. 40. - СПб., 2003), тогда как сводное их издание готовится к выпуску Гарвардским Украинским исследовательским институтом.

Слабым отзвуком прежних научных начинаний выглядит недавно изданная во Львове книга литовской исследовательницы А. Василяускене «Кириллические списки Второго Литовского Статута: палеография, хронология, кодикология», защищенная в качестве диссертационной работы еще в 1990 г. ${ }^{6}$, а также появившийся почти с десятилетним опозданием корпус регестов Русской (или Волынской) Метрики за 1569-1673 гг.,

4. Сравнительно недавно Мицыком была опубликована летопись Бинвильского: Ю. Мицик, « Літопис Яна Бінвільського », в Наукові записки НаУКМА, т. 20 : Історичні науки, ч. 2, К., 2002.

5. Первой увидела свет 5-ая книга записей: Lietuvos Metrika, knyga № 5, Vilnius, 1993.

6. А.-В. Паядайте-Васіляускєне, Кириличні списки Другого Литовського Статуту: палеографія, хронологія, кодикологія, Львів, 2004. 
включающий ее инвентари XVII-XVIII вв. ${ }^{7}$ Русская Метрика представляет собой отдел Коронной Метрики, где сосредоточена документация по воеводствам, присоединенным к Польше в 1569 г. (Волынское, Киевское, Брацлавское) и в 1620 г. (Черниговское). За более чем 100 лет существования Русской Метрики в нее было внесено около 3,5 тыс. актов - а если принять во внимание массовую гибель документов на Украине во время бурных событий середины - второй половины XVII ст., то ценность материалов Коронной канцелярии для украинских земель поистине трудно переоценить.

В 1999 г. была опубликована и одна из наиболее ценных книг Русской Метрики - последняя, 29-ая, охватывающая 1652-1673 гг.8; также планировавшаяся к изданию в рамках международного проекта, базировавшегося на договоре 1980 г. между Польской академии наук и Академией наук СССР, она увидела свет в новой археографической серии «Памятники истории Восточной Европы: Источники XV-XVII вв.», инициированной польскими и российскими учеными. Этот проект «покрывает» и украинские земли - однако привлечение к нему украинских специалистов не имеет системного характера и основывается, скорее, на личных контактах исследователей.

То же можно сказать и об осуществляемом силами Немецкого исторического института (Варшава) международном проекте издания уникального исторического памятника - дневника гданьского купца Мартина Груневега, путешествовавшего в 80-е годы XVI в. по Западной и Восточной Европе; для нас наиболее интересно описание его путешествия по маршруту Львов-Москва и обратно, содержащее уникальную историческую информацию.

Произошла и известная «демонополизация» археографического дела. Так, ряд интересных публикаций был осуществлен в Житомире (в 2001 г. здесь вышла летопись Грабянки, в 2002 г. - «Актовая книга Житомирского гродского уряда 1611 г.»). Во Львове началось издание серии “Monumenta Leopolitana”, в рамках которой в 1998 и 2000 гг. увидели свет «Привилеи города Львова XIV-XVIII вв.» и «Привилеи национальных общин города Львова (XIV-XVIII вв.)». Здесь же появились факсимильное переиздание карты Украины Боплана 1650 г. и первый том сборника «Документы российских архивов по истории Украины» - «Документы к истории запорожского казачества. 1613-1620-е гг.»., подготовленные совместно

7. Г. В. Боряк, ред., Руська (Волинська) Метрика, К., 2002.

8. П. Кулаковський, ред., «Руська (Волинська) Метрика. Книга за 1652-1673 рр.», в Пам'ятки історї Східної Європи. Джерела XV-XVII cm, т. V, Острог; Варшава; Москва, 1999. Параллельно П. Кулаковский издал ценное монографическое исследование Канцелярія Руської (Волинської) Метрики 1569-1673 рр., Острог; Львів, 2002, которое следует признать едва ли не самым весомым вкладом в постсоветское украинское источниковедение, где безраздельно господствуют «малые формы». 
украинскими, российскими и канадскими учеными (второй том сейчас готовится к изданию).

В качестве публикаторов источников выступили одесская Юридическая академия, инициировавшая переиздание Литовских Статутов, и киевский Институт государства и права, издавший в 1993 г. совместно с Институтом археографии сборник «Деловая документация Гетьманщины XVIII ст.», а в 1997 г. - «Права, по которым судится малороссийский народ» (1743 г.). Продолжалась археографическая работа в Институте истории Украины и в Институте языкознания, где с 1970-х годов издавалась серия «Памятники украинского языка» ${ }^{9}$.

Следует подчеркнуть, что смена господствующей исторической парадигмы привела к появлению новых научных приоритетов в изучении позднего средневековья и раннего нового времени, что заметно сказалось на «востребованности» различных групп источников XVI-XVIII вв. Резко понизился интерес к социально-экономической проблематике, активно разрабатывавшейся марксистской историографией (как на еe археографический «реликт» можно указать на сборник документов «Крестьянское движение на Украине 1569-1647 гг.» (К., 1993)); ученые стали осваивать темы, если не табуизированные, то, как минимум, игнорировавшиеся украинской наукой на протяжении многих десятилетий. Не удивительно, что «прорывы» по целому ряду забытых направлений (юдаики, ориенталистики, истории церкви, элитных групп общества, генеалогии) нередко осуществлялись в форме простого переписывания работ столетней давности, без усвоения необходимых источниковедческих навыков $^{10}$; самостоятельная археографическая работа при этом практически не проводилась ${ }^{11}$.

9. В этой серии увидели свет: В.В. Німчук, ред., Книга Київського підкоморського суду (1584-1644), К., 1991; В.Б. Задорожний, А.М. Матвієнко, сост., Волинські грамоти XVI cm., K., 1995.

10. На этом акцентировалось внимание в нашей рецензии на двухтомную Історію церкви та релігійної думки в Украйні В. Ульяновского (К., 1994): О. Русина, “Клептоман у нетрях церковної історії”, Критика, 1999, № 10, с. 20-23. Попутно отметим, что с середины 1990-х гг. публикации, связанные с церковной историей, стимулировались 400-летием Брестской унии. См., например, сборники документов: Оксана Гайова, сост., 1596-1996. Берестейська унія: Документи ЦДІА України у м. Львів, Львів, 1997; М.В. Довбищенко, сост., Документи до історії унії на Волині $i$ Київщині кіния XVI-першої половини XVII cm., К., 2001.

11. Позитивным, впрочем, было то, что наряду с научной «реабилитацией» забытых ученых в исследовательский оборот путем републикации были возвращены некоторые ценные источниковедческие работы - например, статьи Ф. Петруня, содержащие тонкий анализ структуры татарских ярлыков на владение украинскими землями, выдававшихся великим литовским князьям в XV-XVI вв. Другое дело, когда такая републикация осуществлялалсь под чужим именем - как в случае с монографией М. Пасечника, Варшава, Москва і Стамбул у боротьбі за Украӥну (1657-1665), Львів, 1998 , представляющей собой механическое соединение двух рукописей из фондов Научного общества им. Шевченко: Александра Переяславского «К истории войн Руины» и Панаса Феденко «О начале Руины». 
Весьма симптоматичными в этом смысле нужно признать публикации, посвященные празднованию 500-летия введения в Киеве магдебургского права (1999 г.). В появившейся в это время научной и научно-популярной литературе механически тиражировались взгляды исследователей рубежа XIX-XX вв. - вплоть до дословного воспроизведения их работ, как в случае с книгой Р. Делимарского «Магдебургское право в Киеве» $\left(\right.$ К., 1996) ${ }^{12}$. В свою очередь, археографический блок юбилейных изданий был представлен корпусом магдебургских грамот XVI-XVIII вв., готовившимся к печати учеными коллаборационистского толка в период фашистской оккупации Киева (как историческое свидетельство благотворности немецкого «культуртрегерства») ${ }^{13}$, а также подборкой актов XV-XIX вв., опубликованной украинским исследователем Щербиной в 1926 г. $^{14}$; характерно, что в последнем случае издателями был опущен как не «политкорректный» документ XVIII в., содержащий нелицеприятные высказывания киевлян в адрес Ивана Мазепы.

Такая избирательность представляется достаточно естественной для представителей современной «патриотической науки». Не секрет, что нашлось немало историков, которые поддались искушению представить прошлое Украины в упрощенной и лестной для национального самосознания форме, отбрасывая факты, которые не укладываются в их схемы. Такие идеи, такая тональность исторического мышления легко усваиваются массовым сознанием и подхватываются журналистами, писателями, политиками, резонируя на самых различных уровнях, подчас весьма неожиданных. Хорошим примером здесь может служить широко разрекламированный, как «патриотический шедевр», фильм «Молитва за гетмана Мазепу» ведущего украинского режиссера Юрия Ильенко: по его версии, представленной как итог многолетних исторических изысканий, Полтавская битва никогда не имела места в действительности и является выдумкой Пушкина (!).

Среди исследовательских и мифотворческих стратегий, сформировавшихся в 1990-е годы под воздействием изменившейся политикоидеологической конъюнктуры и направленных - сознательно или нет - на выполнение нового социального заказа, особого внимания заслуживают попытки реинтерпретации средневековой истории Украины на основании

12. Характерно, что автор не только «присвоил» чужие работы, но и создал фотофальсификаты киевских привилеев 1494 и 1499 гг. Подробнее см. в нашей рецензии, переизданной в сборнике: О. Русина, Студї з історії Києва та Київськоӥ землі, К., 2005, с. 137-152.

13. Корпус магдебурзьких грамот українським містам: два проекти видань $20-\mathrm{x}-40-\mathrm{x}$ років ХХ ст. - К., 2000.

14. Ср.: В. Щербина, «Документи до історії Києва 1494-1835 рр.», в Український археографічний збірник, т. 1, К., 1926; «Київ у документах Магдебурзького права», Пам 'ять століть, 1999, № 2, с. 54-79. 
нарративных памятников XVII-XVIII вв. Суть проблемы заключается в том, что после монгольского нашествия традиция летописания на украинских землях была фактически прервана на несколько столетий; летописи, возникшие в XVII в., представляли собой сложные исторические компиляции, основанные преимущественно на польских хрониках второй половины XVI ст., полных ошибочных, путаных и тенденциозных суждений об истории Руси. В начале 1990-х годов интерес к последним был актуализирован, помимо прочего, вынашивавшимися в Институте археографии планами публикации в переводе на украинский язык хроник Стрыйковского и Гваньини (первая, несмотря на большую подготовительную работу, так и не была издана; вторая время от времени публикуется в отрывках Ю. Мицыком).

Фактором, способствовавшим популярности Стрыйковского у современных ученых, явилась, в известной мере, схожесть их интенций, а, именно, обоюдное желание пролонгировать и возвысить национальную историю. Забвение славного прошлого, по Стрыйковскому, объяснялось отсутствием в прежние времена историков, способных зафиксировать величие деяний предков; в противном случае слава литовцев давно затмила бы героев Греции и Рима:

... gdy by Litwa $\mathrm{z}$ dawna cnych poetów miała

Których by pismem dzielność ich sławę swą brała,

Nalazł by dziś z Litawów Achillesów męźnych,

Uirzał by z Żmodzi, z Rusi Hektorów potęźnych,

Wstyd by dziś było Grecji za hetmany swoje,

Skrył by Julius rzymski przed Litwą swe boje ${ }^{15}$.

Пафос Стрыйковского разделяют те историки Украины, которым «тесно» в пределах второго тысячелетия; они оперируют топосом разорения и уничтожения библиотек, в которых были сокрыты свидетельства былого величия нации - тем более, что он издавна присутствует в местной интеллектуальной традиции. Так, в XVII в. издатели Киево-Печерского Патерика сетовали в своем предисловии, что «Житие» основателя монастыря Антония «через похищение ратное от нас удалися» ${ }^{16}$ - и, по существу, так же объясняли Боплану «ученейшие» киевляне отсутствие сведений о прошлом своего края: по их словам, опустошительные войны вызвали гибель библиотек ${ }^{17}$. На вызванные войнами опустошения ссылался и

15. M. Stryjkowski, Kronika Polska, Litewska, Żmódzka i wszystkiej Rusi, Warszawa, 1846, cz. 1 , s. XXV.

16. Цит. по: Ю.А. Артамонов, «Проблема реконструкции древнейшего Жития Антония Печерского», в Средневековая Русь, М., 2001, вып. 3, с. 6.

17. Боплан, Опис України, с. 33. 
хронист Феодосий Софонович: «Киев долго з монастрми опустелыми стоял, тогды и писма погинули» ${ }^{18}$.

Впрочем, кроме войн и пожаров, был еще один фактор, под воздействием которого пустели местные библиотеки. С переносом митрополичьей кафедры на северо-восток Руси развернулся процесс, который можно было бы дефинировать, прибегая к современной терминологии, как «вывоз культурных ценностей». Практика, инициированная митрополитом Максимом, переехавшим во Владимир «со всем своим житьем», нашла продолжение в деятельности его преемников, которые, словами окружного послания Витовта (1415г.), «всю честь церковную киевское митрополии инде относили». Несомненно, значительную часть этой «чести», ввиду высокой ценности рукописей, составляли книжные богатства. Сохранилась эта традиция и после фактической ликвидации единства общерусской митрополии: в одной из редакций Кормчей Вассиана Патрикеева (20-е гг. XVI в.) содержится ссылка на «Правила» чернигово-брянского епископа Евфимия, «что вывез их с собою» в 1464 г., когда отказался признавать духовный авторитет проуниатского митрополита Григория Болгарина и эмигрировал в Москву ${ }^{19}$.

Таким образом, на протяжении значительного исторического промежутка, охватывавшего 2-ю половину XIII-XV ст., происходило интенсивное распыление сосредоточенных в Киеве книжных богатств. В итоге, в XVI в. «киевский летописец» значился даже среди книг Сигизмунда I - тогда как в Печерском монастыре отсутствовали не только древнерусские летописи, но и «Житие» его основателя Антония, на поиски которого в 1561 г. отправился в Москву уроженец Каменца-Подольского иеродиакон Исайя Каменчанин, представлявший интересы кружка виленских просветителей, вынашивавших замысел печатать книги, адресованные «народу русскому литовскому да и русскому московскому». Как известно, миссия Исайи не удалась (приехав в Россию «на малое время», он, в силу обстоятельств, остался там «на житие»); есть, однако, определенные основания думать, что его надежды отыскать в Москве нужную книгу были отнюдь не напрасны: в составленном около 1611 г. описании царской библиотеки фигурирует «книга в полдесть Житие Антония Печерскаго» ${ }^{20}$.

Известно, что именно на северо-востоке Руси сохранились в постмонгольский период и древнерусские традиции летописания. Однако некоторые нынешние историки, реконструируя события XIV-XV вв., предпочитают скупым синхронным данным северо-восточных летописных

18. Софонович, Хроніка з літописців стародавніх, с. 260.

19. Детальнее см.: О. Русина, Україна під татарами і Литвою, К., 1998, с. 283-285.

20. С. Белокуров, О библиотеке московских государей в XVI столетии, М., 1898, c. 321; Н.Н. Зарубин, сост., Библиотека Ивана Грозного: Реконструкция и библиографическое описание, Л., 1982, с. 37. 
сводов цветистые и пространные описания, содержащиеся в польских хрониках и восходящих к ним поздних украинских летописях. Благодаря этой переоценке информационного потенциала указанных источников (в первую очередь - хроники Стрыйковского) в современной историографии получил второе рождение легендарный рассказ о походе литовского князя Гедимина на Волынскую и Киевскую земли, отброшенный как недостоверный еще в начале прошлого столетия; сформировалась концепция Синеводской битвы как события, предваряющего хронологически и значительно превосходящего своими масштабами битву на Куликовом поле ${ }^{21}$.

Были предприняты попытки (В. Ставиский) выделить из состава Густынской летописи мифический летописец Владимира Ольгердовича (первого литовского князя, занимавшего киевский стол в последней трети $\mathrm{XIV}$ в.), а в украинском хронографе «обнаружился» факт пользования ее составителя «хроничкой» авторства «современника Нестора - печерского летописца Вениамина» ${ }^{22}$.

Более того - киевский исследователь П. Сас «нашел» среди исторических пассажей «Катехизиса» Лаврентия Зизания (1627 г.) следы призрачного «летописца Аскольда» - «древнейшие летописные записи IX-X вв.» $^{23}$. Это открытие было подвергнуто аргументированной критике А. Толочко, который справедливо отметил, что оно пребывает в русле современных взглядов на Украину как на «нетронутый заповедник, в котором, в отличие от великорусских земель, сохранились очень старые, едва ли не домонгольского времени, и в Москве уже утраченные летописные тексты [вплоть до «летописей антов» (!), если верить С. Плачинде - E.P.], которые внезапно всплывают после столетий забвения в литературе XVII в.,

21. Детальнее эти проблемы рассмотрены нами в публикациях: О. Русина, «Київська виправа Гедиміна (текстологічний аспект проблеми)», Записки Наукового товариства iм. Шевченка, т. 231, Львів, 1996, с. 147-157; Та же, «Синьоводська “Задонщина": історична першість чи історіографічний гібрид?», Український гуманітарний огляд, Київ, 1999, вып. 1, с. 178-189; Та же, Студї̈ з історії..., с. 314-340. Отметим, впрочем, что украинские ученые отнюдь не одиноки в своих попытках выявить в составе хроники Стрыйковского некие сегодня утраченные источники; примером здесь может служить обнаруженная А.И. Роговым «Русская хроничка», в основу которой была положена якобы неизвестная Печерская летопись рубежа XI-XII ст. (А.И. Рогов, Русско-польские культурные связи в эпоху Возрождения (Стрыйковский и его Хроника), М., 1966, с. 115-122; Д. Александров, Д. Володихин «"Русская хроничка” Стрыйковского», Вестник Московского ун-тета, сер. 8: История, 1993, № 2, с. 70-74).

22. См. критику этих воззрений: O. Rusyna, «On the Kyivan Princely Tradition from the Thirteenth to the Fifteenth Centuries», Harvard Ukrainian Studies, 18 (3/4), December 1994, 177; О. Русина, «До ідентифікації києво-печерського літописця Веніаміна», Ковчег, Львів, Вып. 3, 2002, с. 121-130; Та же, Студї̈ з історії Києва..., с. 295-313.

23. П. Сас, «Концепція хрещення Русі Лаврентія Зизанія: (До питання про методи ренесансного історизму в українській літературі та історіографії другої половини XVI першої третини XVII ст.)», в Записки Наукового товариства ім. Шевченка, т. 225, Львів, 1993, с. 204-231. 
а после этого [...] таким же таинственным образом вновь растворяются в черной мгле неизвестности». Авторское резюме было довольно неутешительным: «Отрадно, что в нашей науке возрождается интерес к текстологическим поискам в летописании. Печально, что такие попытки нередко ведут к продуцированию мифов, а не к их устранению» ${ }^{24}$.

Объяснение этому следует, несомненно, искать в упомянутой выше смене исследовательских приоритетов, когда ученые, не обладая достаточной подготовкой, стали осваивать новые для себя темы и типы средневековых источников $^{25}$. При этом одно дело, когда речь шла о медиевистах - как, например, о том же П. Сасе, который занялся текстологией нарративных памятников, будучи специалистом по урбанистике. Хуже, когда источниками XVI-XVIII вв. начали заниматься бывшие историки партии, Октябрьской революции и т.п., чья специальность в 90-х годах потеряла свою raison d'être. Некоторые из них, привычно следуя «генеральной линии», занялись «казаковедением», привнеся в него прямолинейность, идущую от буквального понимания социального заказа. Не удивительно, что под их пером казачество оказалось носителем не только традиций государственности и всех христианских добродетелей, но еще и «экологического мировоззрения», особых форм религиозности, собственной педагогики и боевых искусств, перед которыми блекнут восточные единоборства. Понятно, что при этом были выработаны особые стратегии, позволяющие обосновать факты, отсутствующие в традиционных нарративах/документах; среди них следует упомянуть полную неразборчивость в подборе источников, опору на памятники вроде сказок, былин, преданий в записи XIX-XX вв., акцентирование некой тайной традиции, устно передаваемой из поколения в поколение в узком кругу посвященных. Настораживает, что в настоящее время идеи, продуцируемые мнимыми «козаковедами», интенсивно проникают в учебную и наукообразную литературу ${ }^{26}$.

Правда, энергичное акцентирование роли казачества в истории Украины имело своим позитивным результатом развитие поздне-

24. О. Толочко, «Ще раз про “Літопис Аскольда" (Дещо про міфи української текстології)», в Записки Наукового товариства ім. Шевченка, т. 240, Львів, 2000, c. $690-701$.

25. Особенно «опасными» в этом смысле оказались синодики, чьи данные порой трактуются с недопустимой вольностью. Характерным примером здесь может служить расцененная в литературе как источниковедческий курьез попытка выделить в составе Киево-Печерского помянника, составленного на рубеже XV-XVI вв., поименный ряд из 25 поколений предков одного из киевских бояр, в числе которых оказался даже летописец Нестор (Н.М. Яковенко, «Україна аристократична: Генеалогічні новели», в О.В. Русина, сост., На переломі: Друга половина XV - перша половина XVI cm., К., 1994, с. 322-323).

26. Подробнее см.: Ю. Мицик, «Бойовий гопак або язичество на марші», в его же $3 a$ віру православну!, Київ, 2004, с. 65-68; О. Русина, «Дикі танці», Критика, № 6, 2005, c. $19-22$. 
средневековой археологии (называемой в настоящее время «казацкой»), пополнившей наши сведения об этом социополитическом феномене, и вызвало к жизни ряд важных археографических начинаний: стал издаваться архив Запорожской Сечи ${ }^{27}$, увидела свет серия «Универсалы украинских гетманов» $^{28}$, появились отдельные ценные публикации ${ }^{29}$, а в традиционном издании «Памятники украинского языка» - новая подсерия «Казацкие летописи», пока что представленная лишь упомянутым выше житомирским изданием летописи Григория Грабянки.

Не вызывает, однако, энтузиазма то, что содержащаяся в этой и подобных летописях хазарская теория происхождения «казако-русского народа», производная от тогдашнего состояния историографии, ныне популяризируется в околонаучной литературе, а в академической периодике ее появление объясняется достаточно экстравагантно: тем, что после Освободительной войны 1648-1654 гг. «в среде украинской казацкой старшины [...] оказалось немало лиц еврейского происхождения»; a поскольку иудейство было господствующей религией в Хазарском каганате, получается, что «хазарская идея» была заложена в казачестве «едва ли не на генетическом уровне» ${ }^{30}$.

Публикуются в современных научных изданиях и работы историковдилетантов, претендующих на «революционные открытия» в источниковедении. Хорошим примером здесь может служить киевский эксхимик Н. Жарких с его недавними откровениями относительно происхождения знаменитого трактата Михалона Литвина «О нравах татар, литовцев и москвитян» ${ }^{31}$. Весьма симптоматично, что, «корректируя» существующие научные представления об этом уникальном памятнике середины XVI ст., он оперирует заведомо устаревшей историографией

27. Сначала увидело свет описание дел этого фонда (Л.З. Гісцова, Л.Я. Демченко, сост., Архів Коша Нової Запорізької Січі: Опис справ. 1713-1776, К., 1994), а затем началась его корпусная публикация, насчитывающая в настоящее время четыре тома (П.С. Сохань, гол. редкол., Архів Коша Нової Запорозької Січі: Корпус документів 1734-1775, т. 1-4, К., 1998).

28. Універсали Богдана Хмельницького, К., 1998; Універсали Івана Мазепи, К.; Львів, 2002; Універсали українських гетьманів від Івана Виговського до Івана Самойловича (1657-1687), K., 2004.

29. Листи до Івана Сірка, К., 1995; Реєстр Війська Запорозького 1649 р., К., 1995.

30. Украӥнський історичний журнал, № 1, 2004, с. 143-144.

31. М. Жарких, Трактат Михалона Литвина 1615 року як соціальна утопія та історичне джерело, в Записки Наукового товариства ім. Шевченка, т. 240, Львів, 2000, с. 7-42. Развивая гипотезу Е. Охманьского, предположившего, что под именем Михалона Литвина скрывается секретарь великокняжеской канцелярии Венцлав Миколаевич, входивший в число доверенных лиц канцлера Альбрехта Гаштольда, и отталкиваясь от факта знакомства последнего с Сигизмундом Герберштейном, автор утверждает, что при написании своего трактата Венцлав Миколаевич воспользовался некими черновыми заметками Герберштейна, который, в свою очередь, получил от Гаштольда описание Киевской земли, якобы составленное вскоре после назначения его отца, Мартина Гаштольда, киевским воеводой. 
вопроса (ему, например, осталось неизвестным московское издание трактата Михалона Литвина 1994 г. $^{32}$ ) и терминологией, далекой от академической (например, по его наблюдениям, «знакомство Литвина с Библией не сводилось к „курсу молодого бойца”»).

Впрочем, эта проблема актуальна на всем постсоветском пространстве; для примера достаточно вспомнить феномен Фоменко или белорусского математика Ильина, который «отрекомендовывается» как исследователь, на протяжении нескольких лет выдвинувший «свои версии авторства „Слова о полку Игореве”, „Повести временных лет”, „Истории русов” и „Записок янычара"» 33 .

Проблема псевдоисториков усугубляется проблемой псевдоисточников, которыми они охотно манипулируют. Речь идет не о средневековых фальсификатах (хотя, в силу отмеченного нами снижения источниковедческой культуры исследователей, ныне в научном обороте можно встретить такие классические их образчики, сфабрикованные в XVI в., как грамота Любарта 1322 г., грамота на ставропигию Киево-Печерскому монастырю 1481 г. и др.), а о новейших подделках.

Нельзя не заметить, каких впечатляющих размеров достигло их распространение - вплоть до того, что они репродуцируются в хрестоматиях для школ и ВУЗов как достоверные исторические памятники. Так называемая «Влесова книга» (перевод которой на современный украинский язык несколько лет назад едва не выдвинули на престижнейшую премию Т.Г. Шевченко $)^{34}$ всячески популяризируется как «Святое Писание украинцев» и служит духовным знаменем для новоявленных язычников. Не меньшим успехом пользуются шарлатанские трактовки источников неясного происхождения. К последним относится, в первую очередь, «манускрипт Войнича» - ставшая объектом многочисленных паранаучных спекуляций шифрованная рукопись XVI ст., хранящаяся в библиотеке Йельского университета, которую криптолог-самоучка Д. Стойко интерпретировал как древнейший памятник украинской литературы - «Послание ариев хазарам».

32. Михалон Литвин, О нравах татар, литовцев и москвитян, М., 1994. Нужно, впрочем, отметить, что отрыв от достижений российской археографии и историографии заметен во многих работах современных украинских авторов. См. в этой связи нашу рецензию на фундаментальный труд О. Купчинского, «Акти та документи Галицько-Волинського князівства XIII - першої половини XIV століть: Дослідження. Тексти, (Львів, 2004)», в он же, Український археографічний щзорічник, К., 2006, Вып. 10/11, с. 790-792.

33. Гістарычная брама, 2001, № 1, с. 2.

34. См. о ней, в частности: Г. Грабович, «Слідами національних містифікацій», Критика, № 6, 2001; И.Н. Данилевский, «Попытки «улучшить» прошлое: «Влесова книга» и псевдоистории», в он же, Древняя Русь глазами современников и потомков (IX-XII вв.), M., 2001, c. 314-326; P. Urbanczyk, "“Vlesova kniga" - oszustwo niedoskonale», in Słowianie $i$ ich sqsiedzi we wczesnym Średniowieczu, Lublin; Warszawa, 2003, s. 91-98. 
На Украине такие парадоксальные явления пока что рас-сматриваются на уровне единичных реплик в литературе, критических заметок в прессе и т.д.; однако они, без сомнения, должны анализироваться в связи с общим состоянием науки и культурной ситуацией в стране, позволяющей подменять профессионализм патриотической риторикой, а то и просто шарлатанством. Более того - плодотворным видится и их анализ в более широком постсоветском контексте, под углом зрения исследовательских стратегий, возникших как форма социально-политической адаптации науки к новым историческим условиям. Эти стратегии составляют неотъемлемую часть процессов становления новых национальных историографий, которые проходят гораздо сложнее, чем это можно было ожидать, и заключают в себе множество интеллектуальных коллизий, связанных с формированием патриотического дискурса.

В этой связи представляется интересным взглянуть на современное состояние изучения и публикации источников очерченного периода в сравнительном плане. Очевидно, что научные процессы на постсоветском пространстве имеют много сходных черт; с другой стороны, есть и различия, обусловленные политическими процессами, своеобразием организационной структуры науки, степенью ее открытости методологическим новшествам и вовлеченности в глобальный контекст - не говоря уже о неравенстве «стартовых позиций». Не секрет, например, что уровень украинской советской археографии и источниковедения был заведомо ниже российского; тем не менее ряд примеров свидетельствует о том, что ныне, наряду с рядом успехов в этой сфере, и в России заметен известный «откат» от прежних позиций. Думается, что в перспективе обсуждение этих проблем может дать интересный материал для компаративистики.

Institut d'histoire de l'Ukraine

Académie nationale des sciences d'Ukraine

erusina@ukr.net 